\title{
Retinoblastoma pT4 TNM Finding v7
}

National Cancer Institute

\section{Source}

National Cancer Institute. Retinoblastoma pT 4 TNM Finding v7. NCI Thesaurus. Code C88736.

Retinoblastoma with tumor invading optic nerve to resection line or exhibiting extraocular extension elsewhere. (from AJCC 7th Ed.) 